\title{
Transformation of the Process of Hiring Employees Under the Influence of Information Technologies
}

\author{
Olga O. PaVloshchuK ${ }^{i}, V_{\text {IKTORIIA E. MeLnYChuK }}{ }^{i i}$, \\ NADIIA V. ROSHCHYNA iii
}

\begin{abstract}
The socio-economic and political transformations in the country cannot be perceived without the implementation of information technology. Nowadays, Internet resources are actively used in all spheres of life, so personnel management departments, following the example of foreign recruitment companies, adapt the system of selection of personnel to the modern technological realities. Human capital is still one of the most important factors in the country's development. It was approved that the proper selection of a qualified specialist is the key to the success of any company, organization, enterprise because the staff influences their efficiency and competitiveness in the occupied market segment. On this basis, it should be noted that the output of the Human Resource department is crucial. Staffing is not possible without the use of information technology and the Internet. Analyzing the existing changes in the field of hiring employees, we verified that new technologies are implemented solidly. Head-hunters and recruiters use dedicated social networking sites and job search sites to recruit highly qualified personnel. Recent advances in marketing, such as targeted advertising, are also actively and purposefully used to attract the attention of potential employees. Moreover, specialized software is being developed to simplify the selection and screening system for those candidates who do not meet the requirements of the enterprise. It should be noted that the development of information technology has fundamentally affected the change in the relationships and interactions of people in society, involving all spheres of life. Looking at people around the world who spend a lot of time in the virtual space and want to find a particular job, it should be confirmed that there is no longer a need to print it in the newspaper, broadcast it on the radio or to show on television. The results of our research show that the advertisement for the job position can be entirely spread on the Internet in the nearest future. Information technology has made adjustments to the specifics of hiring qualified personnel in the world, and in particular in Ukraine. The widespread availability of information resources in the world has fundamentally changed the policies of Human Resource Management departments and the tactics of their specialists. It has been done a lot in the development of the Human Resource department in Ukraine, but several unresolved issues should be overcome. It's the quandary of the future.
\end{abstract}

Keywords: information technology, human capital, human resources management, social networks.

Abbreviations:

HR - Human Resource;

HRM - Human Resource Management;

CEO - Chief Executive Officer;

CFO - Chief Financial Officer;

CIS - Commonwealth of Independent States;

IT - Information Technology;

NASA - National Aeronautics and Space Administration.

${ }^{i}$ Olga O. Pavloshchuk, Student of the Institute of Applied System Analysis, National Technical University of Ukraine "Igor Sikorsky Kyiv Polytechnic Institute";

${ }^{i i}$ Viktoriia E. Melnychuk, Postgraduate Student of the Department of Theoretical and Applied Economics, National Technical University of Ukraine "Igor Sikorsky Kyiv Polytechnic Institute";

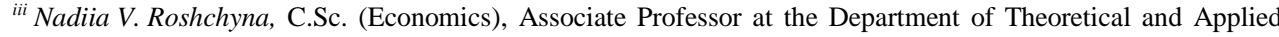
Economics, National Technical University of Ukraine "Igor Sikorsky Kyiv Polytechnic Institute".

(C) O. O. Pavloshchuk, V. E. Melnychuk, N. V. Roshchyna, 2019.

https://doi.org/10.21272/mer.2019.85.05 
О. О. Павлоцук, В. Е. Мельничук, Н. В. Рощина.

Трансформація процесу найму працівників під впливом інформаційних технологій

Introduction. Modern Ukraine is annually going through many social, political, cultural, economic and technological transformations, which are brightly reflected in the legislative field and in many spheres of human activity.

All changes in the state could not but affect the way of human interaction. The Internet has erased the boundaries between communicants: writing a letter or calling to someone in any country is not a problem anymore; special programs and technical means of communication have reduced costs and efforts to the minimum. Television and radio have lost their priority in disseminating information in the society, while at the same time print sources (newspapers and magazines) have gained more "rarity" value. Information has become more accessible through the Internet, which has both positive impacts (distance education, a network of electronic libraries, digital communication, clerical work, etc.) and negative consequences (loss of privacy, cyberbullying, hacking, cybercrime, etc.).

The spread list of social networks, including Facebook, LinkedIn, Telegram, Instagram and others, promoted the development of verbal and non-verbal communication in a distance; the opportunity to share freely and anonymously their impressions, thoughts, beliefs, and feelings - prompted to build person`s own network. Social networks contribute to the elimination of the psychological barriers in our conscious, self-expression and self-confidence, just because the interlocutor is often a stranger, especially in the initial stages of communication. On the other hand, in face-to-face communication outside the network, such people often have phobias - the fear of being unclear, inappropriate, ridiculous, humiliated, and offended.

It`s worth saying that a significant part of bloggers (for comparison, there are 30.6 million bloggers in the US [1]) use online resources to earn money. The forms of getting funds may have different meanings, including collaborations with well-known brands with further targeted advertising; use of certain marked goods for hidden promotion; receiving money by watching a video of a certain number of people; collecting bills from loyal fans in broadcasts and on streams, etc. For example, Ukrainian bloggers who have 50 thousand subscribers earn per month on advertising posts nearly 33 thousand UAH, respectively, those that have 100 thousand -69 thousand UAH, 200 thousand - 180 thousand UAH [2]. It's also should be noted that each Internet platform has its own algorithms to monetize the creative work of bloggers; the price policy, particularly on YouTube, depends on the CPM (cost per mile): for a 1000 video views from Australia the blogger gets \$ 9.6, from Germany - \$ 4.87, from Russia - $\$ 1.55$, from Ukraine - \$0.9, from Belarus - \$ 0.48 [3]. Powerful changes in information technologies naturally affect the method of hiring workers in modern Ukraine.

The HR department is a business card of every firm and organization, as it is the recruitment specialists who interview their future colleagues, defining their professional level and providing comprehensive information about the company's activities and the prospects for professional growth. The link between HR and information technology was the subject of the study by Anthony M. Townsend and James T. Bennett (Human resources and information technology [4]) and Parbudyal Singh and Dale Finn (The effects of information technology on recruitment [5]). However, these studies lack a thorough analysis of changes due to information technology in this field.

Creating electronic databases that have replaced the work of personnel departments has contributed to significant innovations in the Human Resource department. The absence of a 
Olga O. Pavloshchuk, Viktoriia E. Melnychuk, Nadiia V. Roshchyna.

Transformation of the Process of Hiring Employees Under the Influence of Information Technologies

national state program for the training of skilled hiring managers in Ukraine is urging the need to analyse the work of this area, which is due to the relevance of our research.

Professional success and the economic increase of any firm, enterprise or organization depend first of all on human capital. Proper selection of skilled people will contribute to the economic growth of an enterprise or firm, and therefore the problem of creating an efficient Human Resource department remains crucial. Optimizing the work of this department with the use of all possible Internet resources and technical means will help to select better the human resource, and thus the economic development of Ukraine will be provided.

Setting objectives. The main purpose of the study is to analyse the already existing changes in the field of hiring employees and to formulate a forecast for the future of this area, provided the same rapid development of Information Technology.

Methodology. To solve the tasks the following general and specialized methods of scientific research were used: the analytical method (applied in the analysis of the impact of information technology on the process of hiring employees), descriptive (used to describe the dissemination and implementation of IT technologies in Ukraine), statistical method (actualized in the analysis of results of activity recruiters in Ukraine and in the world).

Research results. For the great majority of people, Information Technology made their life more complicated and tenser. Such a thing as private life is gone forever. Privacy is at stake every day. The relatively recent scandal with Facebook is proof of that.

On March 16, 2018, a loud statement was published, declaring that about 50 million Facebook users' data was used by a London-based political consulting firm called Cambridge Analytica to influence the 2016 US election. Cambridge Analytica analysed the election campaign of President Donald Trump. The firm allegedly collected Facebook user data to establish a targeted political election audience to help Trump. Co-founder and patron of Facebook, Mark Zuckerberg apologized for the violation of security and confidentiality, but the damage was already done [6].

Every child who has access to the Internet is under permanent threat. The number of scandals related to harassment on the Internet is growing every year. Sending messages, photos or videos of an offensive or obscene nature, broadcasting anonymous threats or insults, shooting compromising photos and videos, publishing them on the Internet for entertainment, and much more we didn't take on similar scales before the development of Internet technologies. Take for example the game Blue Whale, which was popular in 2017 in the Commonwealth of Independent States countries. It based on the urban legend, a game whose final goal is to commit suicide. The news of the existence of such a pastime, driving teenagers to suicide, was widely proclaimed by the media and provoked a moral panic among the population.

Correspondingly important is the obstacle of hacking. The threat to the information safety of not only the enterprise but also the individual has taken on today ominously large dimensions. In 1999, fifteen-year-old Jonathan James was the first to uncover the system of the US National Space Agency. He managed to gain access by cracking the password of a server belonging to another government agency, after which James stole several important files from NASA, including the source code of the international space station. National Aeronautics and Space Administration estimated the damage at $\$ 1.7$ million. Due to its young age, James was able to escape prison. In 2008, James was interrogated in the case of the largescale hacking of the company TJX, after which he shot himself: in a suicide note he stated that he was doing this because he was innocent but did not believe in justice. Many remained 
О. О. Павлоцук, В. Е. Мельничук, Н. В. Рощина.

Трансформація процесу найму працівників під впливом інформаційних технологій

confident that this was the work of the Secret Service. And this is just one of the most vivid examples of what the opposition between hackers and companies can lead to.

But all these disadvantages lose their meaning when you think that long distances will never become a problem, and all people can easily get any type of information with a single click.

And it's first to start with distant education, which made it possible to gain knowledge on any interesting subject, to destroy the walls of misunderstanding between the teacher and the student, and to build bridges of new opportunities. Such education not only provides high efficiency through the use of convenient tools (presentations, video, chat), but also saves money and is excellent for staff training, especially in organizations where employees often change, and the education itself can be carried out from any location.

Without departing far from education, the creation of a network of electronic libraries also served as a revolutionary event. Total investment in educational projects worldwide in 2015-2016 amounted to 5.5 billion dollars. At the same time, $50 \%$ of the entire market belongs to the United States. However, the growth of Asian markets is expressed in hundreds of per cent [7]. A prominent example is Google Books - a full-text search service for books digitized by Google (over 25 million books from the largest US and European libraries).

Speaking about the benefits of information technology and their impact on modern life management, we cannot but mention digital communication. New concepts emerged to characterize communication: convergence - the ability to transmit information simultaneously, including text, audio and video materials, digital arrays and graphics, and their representation in digital form, which led to a surge in the development of multimedia; compression - information squeezing, which leads to a significant increase in the speed of information exchange, the emergence of the possibility of simultaneous transmission of large arrays of information on one channel; hypertext effects that make it easy to sort, process, change information; a significant reduction in the cost of communication [8]. And as a result of the development of communications against the background of information technology, we have today in the workflow video conferencing, group chats, e-mail and much more. But not only the expression of our thoughts has changed in the workflow, but also the equipment that is used.

Interactive presentation boards, turnstiles at the company's entrance, own servers for each organization, massive use of computers and printers - all this overturned the idea of leading the business process. Much of all these gadgets are also used by professionals in hiring. According to Google's research, $40 \%$ of the use of a PC/laptop is related to the search for information, $29 \%$ - with news/updates of various services and resources [9], so it is not surprising that the workflow is unthinkable without the use of technical equipment and Internet technologies.

The study, conducted by Society for Human Resources Management, shows that recruitment through social networks is becoming increasingly popular, as statistical data shows: $84 \%$ of organizations have already implemented this technique, and $9 \%$ - are planning to use such a selection technology. The main reason for such an approach is the questioning of the involvement of passive job seekers in the list of candidates, which, according to statistics, is about $82 \%$.

The selection process is not homogeneous. It has its own specificity, as evidenced by the analysis of the modern recruiters` experience, $71 \%$ of which assert that the filling of nonmanagement salaried vacancies through social networks significantly reduces the time spent, $67 \%$ - for management positions (managers or directors), $59 \%$ - for candidates for 
Olga O. Pavloshchuk, Viktoriia E. Melnychuk, Nadiia V. Roshchyna.

Transformation of the Process of Hiring Employees Under the Influence of Information Technologies

executive/upper management positions (Chief Executive Officer, Chief Financial Officer etc.) and $53 \%$ - for non-management, hourly employees.

Individual social networks play a significant role in finding candidates, for example, LinkedIn has grown from $85 \%$ in 2011 to $93 \%$ in 2015 in the ranking of sites used to find candidates, Facebook - from $78 \%$ to $63 \%$, and Tweeter - from $11 \%$ to $29 \%$ over the same period. At the same time, the number of people who start leaving links in their CVs to their social networks has increased at least twice [10].

Another important aspect of the current workflow and recruiting industry is the extensive use of databases in the work. Keeping information on the client and candidate, its quick searching and editing - now it is not a problem. In general, digitized documents have turned over the idea of document management. Nevertheless, it is not only about IT development, but also about environmental issues, as a result, more and more companies are implementing the use of tablets and computers instead of printing each file.

With the development of technologies and server connections, the network and communications within the selected number of computers the intranet was included into the use, which made possible to control the data of the firm and to interact more qualitatively in one office. HR specialists can now communicate more effectively about scheduled appointments and teambuilding without spending time on interpersonal consultations.

Modern employment is unfortunately not ideal. It begins primarily with a search for a suitable applicant on the relevant sites. In Ukraine, it can be a work.ua or a rabota.ua. Sometimes candidates are given a test task (which for the most part only eliminates not very interested contestants). Then begins a series of interviews that determine the relevance of the applicant and position. If the position in the field of IT, the technical conference is likely inevitable. Most often, there will be several meetings in order to get a candidate acquainted not only with the recruiter but also with a partner of the firm or organization or team leader. However, even after being hired, the probationary period begins, which is also very stressful and exhausting for an applicant. As a result, a person is under a huge amount of stress (and this is assuming that the interviewer is well prepared professionally and educationally, which is not always the case).

The selection of specialists should begin at the stage of close cooperation between recruiters and future graduates of higher education institutions of Ukraine, which is facilitated by widespread in Ukraine "vacancies fairs" and relevant advertising on the websites and the universities Telegram channels. Advertisements of firms, enterprises and organizations, information on the specifics of their work, outlining prospects for professional growth, and the level of wages - are those aspects that have the biggest interest to contemporary Ukrainian pragmatic youth. To find among the masses of students and be able to distinguish the "necessary person" on the corresponding vacancy - is the main task and showing the manifestation level of professional skills for any modern recruiting professionals.

Conclusions. IT technologies have spread to all spheres of human life: in medical, educational, legal, managerial, and scientific. These innovations are also brightly reflected in the field of employment. However, in this area, which needs constant improvement due to changes in Information Technologies, particularly relatively rapid development and implementation of artificial intelligence and the invention of more advanced algorithms for human resource search.

In Ukraine, it is necessary to continue the active cooperation of recruiters with higher educational institutions, selecting personnel for senior students of the corresponding specialities. An important element in the future is the vocational guidance work of recruiters in 
О. О. Павлоцук, В. Е. Мельничук, Н. В. Рощина.

Трансформація процесу найму працівників під впливом інформаційних технологій

secondary education institutions, which helps modern Ukrainians to orient themselves in the labour market when entering and choosing a future profession. Such a transparent policy will help to preserve the scientific and intellectual resources in Ukraine and reduce the outflow of young specialists abroad.

A large number of specialists in personnel management are trained at the modern high schools of Ukraine. However, the training of highly skilled HR department specialists is still relevant, which is acquainted with the latest achievements of this field in Ukraine and abroad. The problem of modernisation of educational programs for the relevant specialists as well as the problem of modernization of technical means at higher educational institutions is obvious and needs to be solved. Taking into account all these factors will improve the efficiency of HR departments.

\section{References}

1. Number of bloggers in the United States (2016). Retrieved from https://www.statista.com/statistics/187267/number-of-bloggers-in-usa/. Available 01.06.2019.

2. Skilky zaroblyayut bloggery v Ukraini [How much do bloggers earn in Ukraine]. Retrieved from http://ibilingua.com/skilki-zaroblyayut-blogeri-v-ukrayini-yak-otrimuvati-groshi-v-sostsetyah/. Available 01.06.2019.

3. Ptushkin, A. (2018). Vsem kto nenavidit reklamu [To everyone who hates the advertisement]. Retrieved from https://www.youtube.com/watch?v=zHsMMFKjoa8. Available 01.06.2019.

4. Townsend, A., Bennett, J. (2003). Human resources and information technology. Journal of Labor Research, 361-363. Retrieved from https://link.springer.com/article/10.1007/s12122-003-1000-7. Available 01.06.2019.

5. Parbudyal, S., Finn, D. (2003). The effects of information technology on recruitment. Journal of Labor Research, 395-408. Retrieved from https://link.springer.com/article/10.1007/s12122-0031003-4. Available 20.06.2019.

6. Facebook data privacy scandal: A cheat sheet (2019). Retrieved from https://www.techrepublic.com/article/facebook-data-privacy-scandal-a-cheat-sheet/. Available 20.06.2019.

7. Miroshnichenko, D. (2017). Obzor rynka online obrazovaniya [Online Education Market Review]. Retrieved from https://www.openbusiness.ru/biz/business/obzor-rynka-onlayn-obrazovaniya/. Available 09.06.2019.

8. Sovremennyye informationyye technologii $\mathrm{v}$ comunikatsii [Modern IT in Communication]. Retrieved from https://studme.org/31821/menedzhment/sovremennye_informatsionnye_tehnologii_kommunikatsii. Available 01.06.2019.

9. Kolambet, K. 34 facta ob ispolzovanii nami gadgetov [34 facts about our using the gadgets]. Retrieved from https://netpeak.net/ru/blog/about_multi_screen_usage/. Available 09.06.2019.

10. SHRM survey findings (2017). Retrieved from https://www.shrm.org/hr-today/trends-andforecasting/research-and-surveys/Pages/Social-Media-Recruiting-Screening-2015.aspx. Available 20.06.2019.

Трансформация процесса найма работников под влиянием информационных технологий

ОЛЬГА АЛЕКСАНДРОВНА ПАВЛОЩУК", ВИКТОРИЯ ЭДУАРДОВНА МЕЛЬНИчУК ${ }^{* *}$, НАДЕЖДА ВАСИЛЬЕВНА РОЩИНА ${ }^{* * *}$ 
Olga O. Pavloshchuk, Viktoriia E. Melnychuk, Nadiia V. Roshchyna.

Transformation of the Process of Hiring Employees Under the Influence of Information Technologies

*студентка системного анализа Института прикладного системного анализа

Национального технического университета Украинь

«Киевский политехнический институт им. Игоря Сикорского», пр. Акад. Глушкова, 30, г. Киев, 03187, Украина,

тел.: 00-380-99-6237072, e-mail: opavloshchuk@icloud.com

** аспирант кафедры теоретической и прикладной экономики Национального технического университета Украины «Киевский политехнический институт им. Игоря Сикорского»,

бул. Кольиова, 5, кв.76, г. Киев, 03194, Украина,

тел.: 00-380-93-2613291, e-mail: vickikitoria@gmail.com

**** к.э.н., доцент кафедры теоретической и прикладной экономики Национального технического университета Украины «Киевский политехнический институт им. Игоря Сикорского»,

ул. Жолудева, 5, кв.42, Киев, 03134, Украина,

тел .:00-380-67-2203883,e-mail:2203883@ukr.net

Социально-экономические и политические сдвиги в стране невозможно представить без применения информационных технологий. $\mathrm{B}$ наше время интернет ресурсы активно используются во всех сферах жизни, поэтому департаменты управления персоналом, следуя примеру иностранных рекрутинговых компаний, адаптируют систему отбора кадров под современные технологические реалии. Человеческий капитал до сих пор остается одним из важнейших факторов развития страны. Доказано, что правильный подбор квалифицированного специалиста - ключ к успеху любой компании, организации, предприятия, ведь именно персонал влияет на их эффективность и конкурентоспособность в занимаемом сегменте рынка. Исходя из этого, следует отметить, что результат деятельности специалистов по персоналу отдела является важнейшим фактором. Отбор персонала невозможен без использования информационных технологий и сети Интернет. Анализируя существующие изменения в сфере найма персонала, мы подтвердили, что новые технологии внедрены обстоятельно. Сейчас для подбора высококвалифицированного персонала хедхантеры и рекрутеры используют специализированные социальные сети, а также сайты для поиска работы. Последние достижения сферы маркетинга, такие как таргетированная реклама, также активно и целенаправленно используются для привлечения внимания потенциальных работников. Более того, разрабатываются специализированные программные продукты для упрощения системы отбора и отсеивания тех кандидатов, которые не соответствуют требованиям, предъявляемым предприятием. Нужно отметить, что развитие информационных технологий кардинально повлияло на изменение отношений людей в социуме, захватив все сферы жизни. Смотря на людей во всем мире, которые проводят много времени в виртуальном пространстве, и хотят найти определенную вакансию, подтверждаем, что уже не нужно печатать ее в газете, передавать по радио или показывать по телевидению. Результаты нашего исследования показало, что рекламу вакансии будет достаточно распространить только в сети Интернет уже в ближайшем будущем. Информационные технологии внесли коррективы в специфику найма квалифицированных кадров в мире, и в том числе в Украине. Распространенность и доступность информационного ресурса в мире коренным образом изменил политику департаментов по управлению персоналом и тактику их специалистов. В развитии департамента человеческих ресурсов в Украине сделано много, но есть ряд нерешенных проблем, решение которых является задачей на будущее.

Ключевые слова: информационные технологии, человеческий капитал, управление персоналом, социальные сети.

$$
\begin{gathered}
\text { Mechanism of Economic Regulation, 2019, No 3, 49-57 } \\
\text { ISSN 1726-8699 (print) }
\end{gathered}
$$

Трансформація процесу найму працівників під впливом інформаційних технологій 
О. О. Павлощук, В. Е. Мельничук, Н. В. Рощина.

Трансформація процесу найму працівників під впливом інформаційних технологій

\author{
ОЛЬГА ОЛЕКСАНДРІВНА ПАВЛОЩУК, \\ ВІКТОРІя ЕДУАРДІвНА МЕЛЬНИЧУК ${ }^{*}$, \\ НАдІя ВАСилІвна Рощина ${ }^{* * *}$ \\ * студентка системного аналізу Інституту прикладного системного аналізу \\ Національного технічного університету Украӥни \\ «Київький політехнічний інститут ім. Ігоря Сікорського», \\ пр. Акад. Глушкова, 30, м. Київ, 03187, Украӥна, \\ тел .: 00-380-99-6237072, e-mail: opavloshchuk@icloud.com \\ ** аспірант кафедри теоретичної та прикладної економіки Національного технічного \\ університету Украӥни «Київський політехнічний інститут ім. Ігоря Сікорського», \\ бул. Кольчова, 5, кв.76, м. Київ, 03194, Україна, \\ тел.: 00-380-93-2613291, e-mail: vickikitoria@gmail.com \\ **** к.е.н., доцент кафедри теоретичної та прикладної економіки Національного технічного \\ університету Украйни «Київський політехнічний інститут ім. Ігоря Сікорського», \\ вул. Жолудєва, 5, кв.42, Київ, 03134, Украӥна, \\ тел .: 00-380-67-2203883, e-mail:2203883@ukr.net
}

Соціально-економічні та політичні зсуви у країні неможливо уявити без застосування інформаційних технологій. У наш час інтернет ресурси активно використовуються у всіх сферах життя, тому департаменти управління персоналом, йдучи за прикладом іноземних рекрутингових компаній, адаптують систему відбору кадрів під сучасні технологічні реалії. Людський капітал до цього часу лишається одним 3 найважливіших факторів розвитку країни. Доведено, що правильний підбір кваліфікованого спеціаліста - ключ до успіху будь-якої фірми, організації, підприємства, адже саме персонал впливає на їх ефективність та конкурентоспроможність у займаному сегменті ринку. Виходячи з цього, слід зазначити, що результат діяльності спеціалістів 3 персоналу є надважливим. Відбір персоналу неможливий без використання інформаційних технологій та мережі Інтернет. Аналізуючи існуючі зміни у сфері найму працівників, ми підтверджуємо, що нові технології впроваджуються постійно. Наразі для підбору висококваліфікованого персоналу хедхантери та рекрутери використовують спеціалізовані соціальні мережі, а також сайти для пошуку роботи. Останні досягнення сфери маркетингу, такі як таргетована реклама, також активно і цілеспрямовано використовуються для привернення уваги потенційних працівників. Більш того, розроблюються спеціалізовані програмні продукти для спрощення системи відбору та відсіювання тих кандидатів, що не відповідають вимогам, висунутим підприємством. Потрібно зауважити, що розвиток інформаційних технологій кардинально вплинув на зміну відносин людей у соціумі, захопивши усі сфери життя. Дивлячись на людей в усьому світі, які проводять багато часу у віртуальному просторі та хочуть знайти певну вакансію, ми констатуємо факт, що їм вже не потрібно друкувати ії у газеті, передавати по радіо чи показувати по телебаченню. Результати нашого дослідження показали, що рекламу вакансію буде достатньо поширити лише в мережі Інтернет вже в найближчому майбутньому. Інформаційні технології внесли корективи у специфіку найму кваліфікованих кадрів у світі, та зокрема й в Україні. Розповсюдженість та доступність інформаційного ресурсу у світі докорінним чином змінив політику департаментів з управління персоналом та тактику їх спеціалістів. У розвитку департаменту людських ресурсів в Україні зроблено багато, але $\epsilon$ ряд невирішених проблем, вирішення котрих є завданням на майбутнє.

Ключові слова: інформаційні технології, людський капітал, управління персоналом, соціальні мережі.

JEL Codes: J21, J24, J62, O15

References: 10

Language of the article: English 
Olga O. Pavloshchuk, Viktoriia E. Melnychuk, Nadiia V. Roshchyna.

Transformation of the Process of Hiring Employees Under the Influence of Information Technologies

Лimepamypa

1. Number of bloggers in the United States [Electronic resource]. - 2016. - Accessed mode: https://www.statista.com/statistics/187267/number-of-bloggers-in-usa/. (Available at 01.06.2019).

2. Скільки заробляють блогери в Україні [Електронний ресурс]. - Режим доступа : http://ibilingua.com/skilki-zaroblyayut-blogeri-v-ukrayini-yak-otrimuvati-groshi-v-sostsetyah/. (Дата звернення 01.06.2019).

3. Птушкін, А. Для всіх, хто ненавидить рекламу [Електронний ресурс] / А. Птушкін. - 2018. Режим доступа : https://www.youtube.com/watch?v=zHsMMFKjoa8. (Дата звернення 01.06.2019).

4. Townsend, A. (2003). Human resources and information technology [Electronic resource] / A. Townsend, J. Bennett // Journal of Labor Research. - 2003. - P. 361-363. - Accessed mode : https://link.springer.com/article/10.1007/s12122-003-1000-7. (Available at 01.06.2019).

5. Parbudyal, $S$. The effects of information technology on recruitment [Electronic resource] / S. Parbudyal, D. Finn // Journal of Labor Research. - 2003. - P. 395-408. - Accessed mode : https://link.springer.com/article/10.1007/s12122-003-1003-4. (Available at 01.06.2019).

6. Facebook data privacy scandal: A cheat sheet [Electronic resource]. - 2019. - Accessed mode : https://www.techrepublic.com/article/facebook-data-privacy-scandal-a-cheat-sheet/. (Available at 20.06.2019).

7. Мірошниченко, Д. Огляд ринку Інтернет-освіти [Електронний ресурс] / Д. Мірошниченко. 2017. - Режим доступа: https://www.openbusiness.ru/biz/business/obzor-rynka-onlaynobrazovaniya/. (Дата звернення 09.06.2019).

8. Сучасні інформаційні технології в комунікації [Електронний ресурс]. - Режим доступа : https://studme.org/31821/menedzhment/sovremennye_informatsionnye_tehnologii_kommunikatsii. (Дата звернення 01.06.2019).

9. Коламбет, K. 34 факти про наше використання гаджетів [Електронний ресурс] / К. Коламбет. - Режим доступа : https://netpeak.net/ru/blog/about_multi_screen_usage/. (Дата звернення 09.06.2019).

10. SHRM survey findings [Electronic resource]. - 2017. - Accessed mode : https://www.shrm.org/hrtoday/trends-and-forecasting/research-and-surveys/Pages/Social-Media-Recruiting-Screening2015.aspx. (Available at 20.06.2019). 